\title{
13. MALDI-TOF MASS SPECTROMETRY IN TEXTILE INDUSTRY
}

\author{
FLORENTINA-DANIELA MUNTEANU ${ }^{1}$, NICOLAE DINCA ${ }^{1}$, \\ AND ARTUR CAVACO-PAULO ${ }^{2}$ \\ ${ }^{1}$ University "Aurel Vlaicu” Arad, Faculty of Food Engineering, Tourism and \\ Environmental Protection, Department of Chemical and Biological Sciences, \\ Elena Dragoi 2, 310330, Arad, Romania \\ ${ }^{2}$ University of Minho, Department of Textile Engineering, 4800-058 \\ Guimarães, Portugal
}

\begin{abstract}
In this paper are presented the possibilities of using matrix assisted laser desorption ionization time of flight (MALDI-TOF) mass spectrometry in textile industry. MALDI-TOF mass spectrometry it is a convenient, versatile method for characterization and identification of dyes and pigments, and also for characterization of fibers and contaminants of the fabrics.
\end{abstract}

\section{Introduction}

Mass spectrometry is a technique that has been known since the early twentieth century. In 1913, based on the growing understanding of electromagnetic forces, J.J. Thomson was able to separate the two neon isotopes of mass 20 and 22 with his parabola mass spectrograph [1]. Mass spectrometry takes advantage of the force balance that is established when a charged species, in a gas phase, travels through an electric or magnetic field [1]. The trajectory of this species will depend on its mass-to-charge ratio $(\mathrm{m} / \mathrm{z})$. Since the early experiments of Thomson, who analyzed small gaseous atoms and compounds, strategies to vaporize and/or ionize large non-volatile molecules have been developed.

Matrix-assisted laser desorption/ionization (MALDI) and fast-atom bombardment (FAB) are some common desorption/ionization methods, whereas electrospray ionization (ESI) and atmospheric pressure chemical ionization (APCI) are some examples of spraying techniques.

For the separation and to record and store the results, a mass spectrometer contains the following components:

(i) The ion source: where the analyte is brought into the gas phase and ionized.

(ii) The mass filter: necessary for the ions' separation on basis of their mass-tocharge ratios.

(iii) The detector: different $\mathrm{m} / \mathrm{z}$ ions hit the detector and their impacts are turned into electrical signals.

(iv) The system of data acquisition: for the storage of all the electrical signals that are generated from the detector. 
Matrix Assisted Laser Desorption/Ionisation-Time of Flight-Mass Spectrometry (MALDI-TOF-MS) was developed in the middle to late 1980s (Nobel Prize winner 2002) [2-5] for the analysis of molecules with large molar weights.

The first reports demonstrating successful MALDI-TOF-MS biochemical analysis were published in the late 1980s from the labs of Tanaka et al. [2] and Karas and Hillenkamp [5]. Instruments have subsequently become commercially available since 1991 [6]. This implies that the general utilization of MALDI-TOF-MS has emerged as an effective analytical tool to study biomolecules only within the last 15 years. Although relatively young compared to other analytical techniques using mass spectrometry, there has been an enormous increase in the publication of MALDI-TOF-MS methods and applications in the literature [7-9].

MALDI is an ionization technique that, as the name implies, makes use of a photon-absorbing matrix for the desorption and ionization of the analyte [10]. In preparation for a MALDI analysis the analyte is mixed with matrix and cocrystallized on an electrically conducting target, e.g., a stainless steel plate (see Figure 1).

In MALDI the sample is prepared by mixing matrix and analyte in solution at a ratio usually in the range from 100:1 to $50,000: 1$. The matrix is commonly a small aromatic organic solid or liquid with acidic and/or basic functional groups, and has often highly light-absorbing characteristics.

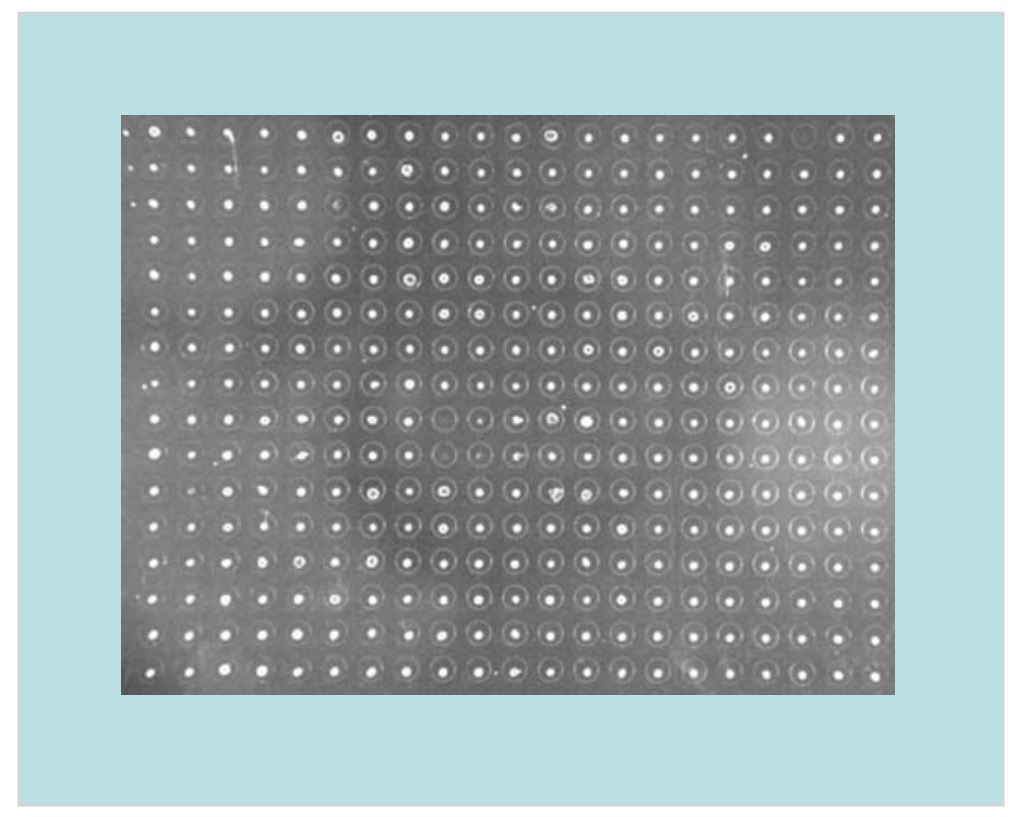

Figure 1. MALDI-TOF stainless steel target plate 
The matrix is often dissolved in solvents such as water, ethanol, methanol, acetone, or mixtures of these $[11,12]$.

The steel plate is then placed in a vacuum and energy in the form of a short laser pulse is applied to the sample and matrix crystal.

The purpose of adding the matrix molecules is that when they are exposed to a laser, usually a nitrogen laser at $337 \mathrm{~nm}$, they become excited and their absorbed energy causes translational motion and ionization of the analyte molecule $[10,13]$. The matrix strongly reduces decomposition of the analyte by absorbing most of the laser pulse energy. As a consequence of this, an "explosion" at the surface causes vaporization of the matrix and the analyte molecules are thereby ejected into the gas phase under vacuum or atmospheric pressure. The ejected material contains both neutral and charged species that are often analyzed with a time-offlight analyzer but can also be analyzed with other mass analyzers. It should be noted that the nature of the ionization mechanism is still being discussed [13,14].

TABLE 1. Common MALDI Matrices

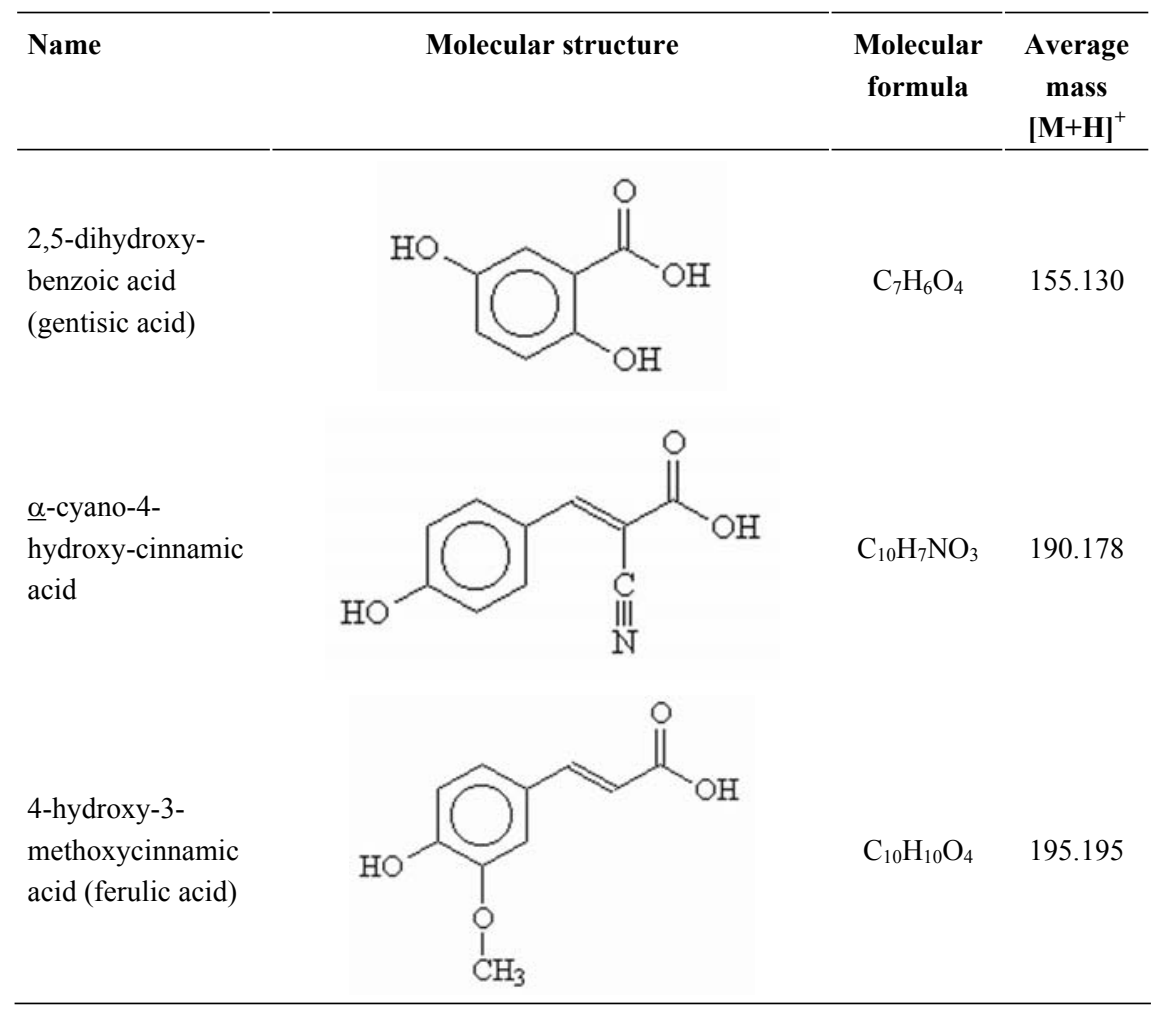

(Continued) 
(Continued)

3,5-dimethoxy-4hydroxy-cinnamic acid (sinapinic acid)<smiles>COc1cc(/C=C/C(=O)O)cc(OC)c1O</smiles>

$\mathrm{C}_{11} \mathrm{H}_{12} \mathrm{O}_{5} \quad 225.222$

3-hydroxy-2pyridine-carboxylic acid (3-hydroxypicolinic acid)<smiles>O=C(O)c1ncccc1O</smiles>

$\mathrm{C}_{6} \mathrm{H}_{5} \mathrm{NO}_{3} \quad 140.119$

nicotinic acid-Noxide<smiles>O=C(O)c1cccnc1O</smiles>

2'-6'-

dihydroxyacetophenone

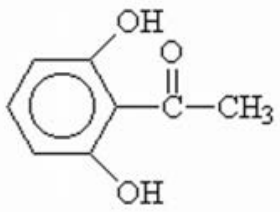

$\mathrm{C}_{8} \mathrm{H}_{8} \mathrm{O}_{3}$ 153.158

The mixture of matrix and sample (normally $0.1-2 \mu \mathrm{l}$ ) is placed onto a target plate, where the solvent is allowed to evaporate, whereby crystals are formed. The matrix and sample may also be deposited in separate individual steps. The drying of the solvent can either be performed at ambient pressure or at reduced pressure. The method used can influence the formation of crystals to a significant extent, which can impact performance and ease of use [11,12]. It is important that the matrix is relatively stable and not evaporate under low pressure conditions. The mechanisms of the MALDI-ionization are not yet fully understood.

Many different approaches have been proposed and it is most likely a combination of several mechanisms that give rise to the ions observed in the spectrometer [10]. Some of the routes proposed are the photoionization, thermal ionization and excited-state proton transfer.

It has even been suggested that the ions are preformed and hence are already present in ionic form before the laser impact and the in-plume processes are initiated [10]. 
One great advantage with MALDI is that the most abundant species are usually single charged molecular ions such as $\left[\mathrm{M}^{+} \mathrm{H}\right]^{+}$(positive ions) or $[\mathrm{M}-\mathrm{H}]^{-}$(negative ions), where $\mathrm{M}$ corresponds to the molar mass of the neutral molecule. The interpretation of the spectrum thereby becomes easier (no multiply charged species interfering). Doubly-charged species may occur but this is not as common as in other MS techniques such as ESI-MS.

As stated above, MALDI is often used together with a time-of-flight (TOF) mass analyzer (Figure 2).

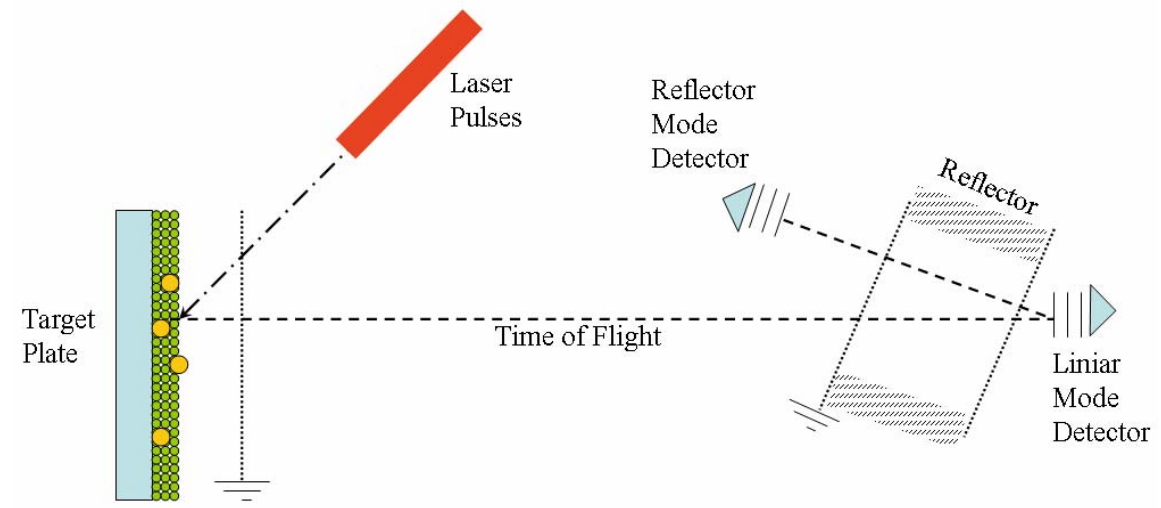

Figure 2. The principle for matrix-assisted laser desorption/ionization with time-of-flight separation

During the desorption process of a sample containing a mixture of several substances, there may be a discrimination against analytes that are less prone to be ionized. This phenomenon is referred to as ion suppression [15], and is often seen in the MALDI analysis of a mixture of peptides. If different peptides are mixed in equimolar amounts and analyzed, the intensities of the corresponding peaks will vary. Easily ionized peptides are known to suppress the ionization of peptides that are less prone to be ionized. This is often the phenomenon that limits the use of internal calibration procedures in MALDI-TOF-MS.

MALDI-TOF-MS has become a powerful tool in a variety of fields [16-21] because it enables molecular weight determination and structural characterization of macromolecules with the characteristics of speed, good mass accuracy, good resolution, excellent sensitivity and high throughput capability. Nevertheless, when searching for low abundant proteins the demands on high mass accuracy and low detection limits are extensive. A sensitive and accurate mass analysis is crucial for obtaining a well-defined peptide mass fingerprint containing as many peptide fragments, stemming from the original protein, as possible. 


\section{Applications of MALDI-TOF-MS in Textile Industry}

MALDI-TOF can be a useful tool to elucidate the structural details of bast fiber peels of developing flax (Linum usitatissimum L.) stem [22].

The polymers that contain galactose are the major matrix components in fiber cell walls of important crops, like flax (Linum usitatissimum L.). The percent of galactose containing polymers represents up $40-80 \%$ of noncellulosic polysaccharides [23,24]. Gur'janov et al. [22] were using an Ultraflex instrument (Bruker Daltonics) equipped with a nitrogen laser of $337 \mathrm{~nm}$. The experiments were done in positive mode and after a delayed extraction time of $200 \mathrm{~ns}$, the ions were accelerated to a kinetic energy of $12,000 \mathrm{~V}$. Thereafter, the ions were detected using the reflector mode. For the preparation of the matrix solution were used $10 \mathrm{mg}$ 2,5-dihydroxybenzoic acid (Bruker Daltonic's) in $700 \mu \mathrm{l}$ water and $300 \mu \mathrm{l}$ acetonitrile. The samples (approximately $20-40 \mu \mathrm{g}$ sugar) were dissolved in $10 \mu \mathrm{l}$ water. After desalting the sample, $1 \mu \mathrm{l}$ of sample solution was placed on a MALDI-TOF-plate together with $1 \mu \mathrm{l}$ of matrix solution and allowed to dry under a constant stream of warm air.

The authors show that the flax galactan is a complex polysaccharide with variable side chain structures. Moreover, the backbone is composed of the common galactan linked to rhamnogalacturonan repeats with a high degree of branching.

Moreover, treatment with purified and well-characterized galactanase does not change the hydrodynamic volume of flax galactan, suggesting a complex "secondary" structure of the polymer.

In 2000, Holland et al. used MALDI-TOF to obtain mass spectra of bacterial proteins from cotton cloth samples contaminated with Shigella flexneri, Escherichia coli, and Aeromonas hydrophila [25].

For this purpose a saturated matrix solution was prepared by dissolving $\alpha$ cyano-4-hydroxycinnamic acid (HCCA) in 2:1 water:acetonitrile $(0.1 \%$ trifluoroacetic acid) solution. The experiments were done in positive mode, the acceleration voltage was set at $28 \mathrm{kV}$ and the instrument's laser (Nd-YAG) output frequency was tripled $(355 \mathrm{~nm})$ for sample desorption.

The authors came to the conclusion that MALDI-TOF mass spectrometry is a rapid method with high potential for detection of biomarker proteins recovered directly from clothing samples contaminated with E. coli, Shigella flexneri, and Aeromonas hydrophila. All three of these species could cause illness through the fecal-oral routes.

Polyamide (nylon) represents a family of synthetic polymers first produced in 1935 by Gerard J. Berchet of Wallace Carother's research group at DuPont.

The first product was a nylon-bristled toothbrush (1938), followed more famously by women's nylon's stockings (1940). Nylon 6.6 was the first commercially successful polymer and the first synthetic fibre to be made entirely from coal, water and air. It was intended to be a synthetic replacement for silk and substituted for it in parachutes after the USA entered World War II in 1941, making stockings hard to find until the war's end. 
Commonly, commercial nylons are manufactured using processes related to either of three basic approaches, namely:

(i) Poly condensation of diamines and dibasic acids, as exemplified by hexamethylene diamine and adipic acid (nylon 6.6)

(ii) Poly condensation of $\omega$-amino acids, as typified by 11 -aminoundecanoic acid (nylon 11)

(iii) Ring-opening polymerisation of lactams, such as $\varepsilon$-caprolactam in nylon 6

The structure of polyamide fibres is defined by both chemical and physical parameters. The chemical ones are related mainly to the constitution of the polyamide molecule and are concerned primarily with its monomeric units, end-groups and molecular weight. The physical parameters are related essentially to chain conformation, orientation of both polymer molecule segments and aggregates and to crystallinity.

In a review by Montaudo et al. are presenting the fundamentals and practice in MALDI of polymers (such as the laser, ion source, ion optics, reflectron, detector, ionization efficiency) as well as to some basic concepts of sample preparation (such as the MALDI matrix and cationization agents). Then, the authors are focus on the measurable quantities of polymers: average molar masses, the chemical formula and the structure of the monomer (actually of the repeat unit), the masses of the chain end groups, etc [26].

Simplicity of sample preparation, rapid spectrum acquisition, high sensitivity, and relative tolerance to impurities make MALDI-TOF attractive for analysis of small molecule analytes. Soltzberg and colab [27] have used this advantages of MALDI-TOF and used it for the identification of dyes and pigments with molecular masses between 200 and 1,100 Da.

For the experiments was used a Bruker Omniflex benchtop MALDI-TOF mass spectrometer equipped with a $337 \mathrm{~nm}$ nitrogen laser. Pulsed ion extraction was employed, with an extraction delay of $300 \mathrm{~ns}$. The experimentation was done in positive and negative mode for each dye and in reflectron mode at the same laser power. The accelerating potential was $14.8 \mathrm{kV}$ for positive ion spectra and 15.8 $\mathrm{kV}$ for negative ion spectra. Each spectrum was the average of 50 laser shots. The reason for which the experiments were run in both negative and positive mode was to quickly classify the dyes as basic or acid based on the comparison of the intensity of negative and positive ion spectra for a particular dye. The base peak data for each dye are listed with negative- or positive-ion spectra, depending on which instrument polarity shows the strongest signal (Table 2).

The results presented in this research paper [27] give information about an unknown dye sample and represents an important aid in identification.

The results obtained by this group show that MALDI-TOF mass spectrometry affords a rapid, versatile, and reliable method for identifying dyes from samples with femtomolar concentrations. Sample preparation involves minimal handling and, therefore, minimal sample loss. The comparison of positive and negative ion 
spectra provides structural information about the dye or pigment class and, in most cases, the identity of the substance. In favorable cases, the spectra can distinguish between isomers.

TABLE 2. Dyes Showing Negative and Positive Ions Mass Spectra

\begin{tabular}{|c|c|}
\hline Dye & Formula \\
\hline \multicolumn{2}{|c|}{ Negative ions mass spectra } \\
\hline Picric acid & $\mathrm{C}_{6} \mathrm{H}_{3} \mathrm{~N}_{3} \mathrm{O}_{7}$ \\
\hline Acid yellow 24 & $\mathrm{C}_{10} \mathrm{H}_{5} \mathrm{~N}_{2} \mathrm{O}_{5} \mathrm{Na}$ \\
\hline Acid yellow 1 & $\mathrm{C}_{10} \mathrm{H}_{4} \mathrm{~N}_{2} \mathrm{SO}_{8} \mathrm{Na}_{2}$ \\
\hline Acid yellow 36 & $\mathrm{C}_{18} \mathrm{H}_{14} \mathrm{~N}_{3} \mathrm{SO}_{3} \mathrm{Na}$ \\
\hline Acid orange 5 & $\mathrm{C}_{18} \mathrm{H}_{14} \mathrm{~N}_{3} \mathrm{SO}_{3} \mathrm{Na}$ \\
\hline Acid red 74 & $\mathrm{C}_{16} \mathrm{H}_{11} \mathrm{~N}_{4} \mathrm{SO}_{5} \mathrm{Na}$ \\
\hline Mordant yellow 1 & $\mathrm{C}_{13} \mathrm{H}_{8} \mathrm{~N}_{3} \mathrm{O}_{5} \mathrm{Na}$ \\
\hline Acid orange 6 & $\mathrm{C}_{12} \mathrm{H}_{9} \mathrm{~N}_{2} \mathrm{SO}_{5} \mathrm{Na}$ \\
\hline Acid orange 20 & $\mathrm{C}_{16} \mathrm{H}_{11} \mathrm{~N}_{2} \mathrm{SO}_{4} \mathrm{Na}$ \\
\hline Acid brown 6 & $\mathrm{C}_{20} \mathrm{H}_{13} \mathrm{~N}_{2} \mathrm{SO}_{4} \mathrm{Na}$ \\
\hline Acid orange 7 & $\mathrm{C}_{16} \mathrm{H}_{11} \mathrm{~N}_{2} \mathrm{SO}_{4} \mathrm{Na}$ \\
\hline Acid red 88 & $\mathrm{C}_{20} \mathrm{H}_{13} \mathrm{~N}_{2} \mathrm{SO}_{4} \mathrm{Na}$ \\
\hline Acid red 9 & $\mathrm{C}_{20} \mathrm{H}_{13} \mathrm{~N}_{2} \mathrm{SO}_{4} \mathrm{Na}$ \\
\hline Acid orange 12 & $\mathrm{C}_{16} \mathrm{H}_{11} \mathrm{~N}_{2} \mathrm{SO}_{4} \mathrm{Na}$ \\
\hline Acid red 13 & $\mathrm{C}_{20} \mathrm{H}_{12} \mathrm{~N}_{2} \mathrm{~S}_{2} \mathrm{O}_{7} \mathrm{Na}_{2}$ \\
\hline Acid red 25 & $\mathrm{C}_{20} \mathrm{H}_{12} \mathrm{~N}_{2} \mathrm{~S}_{2} \mathrm{O}_{7} \mathrm{Na}_{2}$ \\
\hline Acid orange 14 & $\mathrm{C}_{16} \mathrm{H}_{10} \mathrm{~N}_{2} \mathrm{~S}_{2} \mathrm{O}_{7} \mathrm{Na}_{2}$ \\
\hline Acid red 26 & $\mathrm{C}_{18} \mathrm{H}_{14} \mathrm{~N}_{2} \mathrm{~S}_{2} \mathrm{O}_{7} \mathrm{Na}_{2}$ \\
\hline Acid red 17 & $\mathrm{C}_{20} \mathrm{H}_{12} \mathrm{~N}_{2} \mathrm{~S}_{2} \mathrm{O}_{7} \mathrm{Na}_{2}$ \\
\hline Acid red 27 & $\mathrm{C}_{20} \mathrm{H}_{11} \mathrm{~N}_{2} \mathrm{~S}_{3} \mathrm{O}_{10} \mathrm{Na}_{3}$ \\
\hline Acid orange 10 & $\mathrm{C}_{16} \mathrm{H}_{10} \mathrm{~N}_{2} \mathrm{~S}_{2} \mathrm{O}_{7} \mathrm{Na}_{2}$ \\
\hline Acid red 44 & $\mathrm{C}_{20} \mathrm{H}_{12} \mathrm{~N}_{2} \mathrm{~S}_{2} \mathrm{O}_{7} \mathrm{Na}_{2}$ \\
\hline Acid red 18 & $\mathrm{C}_{20} \mathrm{H}_{11} \mathrm{~N}_{2} \mathrm{~S}_{3} \mathrm{O}_{10} \mathrm{Na}_{3}$ \\
\hline Acid red 41 & $\mathrm{C}_{20} \mathrm{H}_{10} \mathrm{~N}_{2} \mathrm{~S}_{4} \mathrm{O}_{13} \mathrm{Na}_{4}$ \\
\hline Acid red 33 & $\mathrm{C}_{16} \mathrm{H}_{11} \mathrm{~N}_{3} \mathrm{~S}_{2} \mathrm{O}_{7} \mathrm{Na}_{2}$ \\
\hline Acid red 1 & $\mathrm{C}_{18} \mathrm{H}_{13} \mathrm{~N}_{3} \mathrm{~S}_{2} \mathrm{O}_{8} \mathrm{Na}_{2}$ \\
\hline Acid violet 7 & $\mathrm{C}_{20} \mathrm{H}_{16} \mathrm{~N}_{4} \mathrm{~S}_{2} \mathrm{O}_{9} \mathrm{Na}_{2}$ \\
\hline Acid yellow 23 & $\mathrm{C}_{16} \mathrm{H}_{9} \mathrm{~N}_{4} \mathrm{~S}_{2} \mathrm{O}_{9} \mathrm{Na}_{3}$ \\
\hline Acid black 1 & $\mathrm{C}_{22} \mathrm{H}_{14} \mathrm{~N}_{6} \mathrm{~S}_{2} \mathrm{O}_{9} \mathrm{Na}_{2}$ \\
\hline Direct red 28 & $\mathrm{C}_{32} \mathrm{H}_{22} \mathrm{~N}_{6} \mathrm{~S}_{2} \mathrm{O}_{6} \mathrm{Na}_{2}$ \\
\hline Direct yellow 4 & $\mathrm{C}_{26} \mathrm{H}_{18} \mathrm{~N}_{4} \mathrm{~S}_{2} \mathrm{O}_{8} \mathrm{Na}_{2}$ \\
\hline Acid red 151 & $\mathrm{C}_{22} \mathrm{H}_{15} \mathrm{~N}_{4} \mathrm{SO}_{4} \mathrm{Na}$ \\
\hline Acid red 115 & $\mathrm{C}_{24} \mathrm{H}_{18} \mathrm{~N}_{4} \mathrm{~S}_{2} \mathrm{O}_{7} \mathrm{Na}_{2}$ \\
\hline Acid red 73 & $\mathrm{C}_{22} \mathrm{H}_{14} \mathrm{~N}_{4} \mathrm{~S}_{2} \mathrm{O}_{7} \mathrm{Na}_{2}$ \\
\hline Acid blue 3 & $\mathrm{C}_{27} \mathrm{H}_{31} \mathrm{~N}_{2} \mathrm{~S}_{2} \mathrm{O}_{7} \mathrm{Na}$ \\
\hline
\end{tabular}




\begin{tabular}{ll}
\hline Acid green 5 & $\mathrm{C}_{37} \mathrm{H}_{34} \mathrm{~N}_{2} \mathrm{~S}_{3} \mathrm{O}_{9} \mathrm{Na}_{2}$ \\
Acid yellow 73 & $\mathrm{C}_{20} \mathrm{H}_{12} \mathrm{O}_{5}$ \\
Acid red 87 & $\mathrm{C}_{20} \mathrm{H}_{6} \mathrm{O}_{5} \mathrm{Br}_{4} \mathrm{Na}_{2}$ \\
Acid red 51 & $\mathrm{C}_{20} \mathrm{H}_{6} \mathrm{O}_{5} \mathrm{I}_{4} \mathrm{Na}_{2}$ \\
Acid yellow 3 & $\mathrm{C}_{18} \mathrm{H}_{8} \mathrm{NS}_{3} \mathrm{O}_{11} \mathrm{Na}_{3}$ \\
Murexide & $\mathrm{C}_{8} \mathrm{H}_{8} \mathrm{~N}_{6} \mathrm{O}_{6}$ \\
Mordant red 11 & $\mathrm{C}_{14} \mathrm{H}_{8} \mathrm{O}_{4}$ \\
Alizarin red PS & $\mathrm{C}_{14} \mathrm{H}_{8} \mathrm{SO}_{8}$ \\
Mordant red 2 & $\mathrm{C}_{14} \mathrm{H}_{7} \mathrm{SO}_{8} \mathrm{Na}$ \\
Acid blue 83a & $\mathrm{C}_{45} \mathrm{H}_{44} \mathrm{~N}_{3} \mathrm{~S}_{2} \mathrm{O}_{7} \mathrm{Na}$
\end{tabular}

Positive ions mass spectra

\begin{tabular}{ll} 
Basic orange 2 & $\mathrm{C}_{12} \mathrm{H}_{13} \mathrm{~N}_{4} \mathrm{Cl}$ \\
Basic brown 4 & $\mathrm{C}_{21} \mathrm{H}_{26} \mathrm{~N}_{8} \mathrm{Cl}$ \\
Basic yellow 2 & $\mathrm{C}_{17} \mathrm{H}_{22} \mathrm{~N}_{3} \mathrm{Cl}$ \\
Basic green 4 & $\mathrm{C}_{23} \mathrm{H}_{27} \mathrm{~N}_{2} \mathrm{OCl}$ \\
Basic green 1 & $\mathrm{C}_{27} \mathrm{H}_{33} \mathrm{~N}_{2}$ \\
Basic violet 14 & $\mathrm{C}_{20} \mathrm{H}_{20} \mathrm{~N}_{3} \mathrm{Cl}$ \\
Basic violet 3 & $\mathrm{C}_{25} \mathrm{H}_{30} \mathrm{~N}_{3} \mathrm{Cl}$ \\
Basic blue 11 & $\mathrm{C}_{29} \mathrm{H}_{32} \mathrm{~N}_{3} \mathrm{Cl}$ \\
Basic red 1 & $\mathrm{C}_{28} \mathrm{H}_{31} \mathrm{~N}_{2} \mathrm{O}_{3} \mathrm{Cl}$ \\
Solvent red 49 & $\mathrm{C}_{28} \mathrm{H}_{31} \mathrm{~N}_{2} \mathrm{O}_{3} \mathrm{Cl}$ \\
Basic red 2 & $\mathrm{C}_{20} \mathrm{H}_{19} \mathrm{~N}_{4} \mathrm{Cl}$ \\
Basic blue 9 & $\mathrm{C}_{16} \mathrm{H}_{18} \mathrm{~N}_{3} \mathrm{SCl}$ \\
Basic blue 26 & $\mathrm{C}_{33} \mathrm{H}_{32} \mathrm{~N}_{3} \mathrm{Cl}$ \\
\hline
\end{tabular}<smiles>Nc1c(N=Nc2ccc(OCCOS(=O)(=O)O)cc2)c(S(=O)(=O)O)cc2cc(S(=O)(=O)O)c(N=Nc3ccc(S(=O)(=O)OCCCOS(=O)(=O)O)cc3)c(O)c12</smiles>

Figure 3. Chemical structure of the reactive dye Ostazine Black V-B

Reactive dyes are a class of colorants and are designed to form a covalent bond with the substrate of application, in contrast to other classes, where the coloration is dependent on physical adsorption or mechanical retention. The capability of forming chemical bonds is based on the dualistic structure of the molecule which is composed of a colored part (chromophore) and a reactive system. The colored part consists of a chromogenic system with groups that encourage solubility.

Chroma-Keull and coworkers [28] used MALDI-TOF-MS for the determination of reactive dyes and monitoring of their hydrolysis. As a model for the class of reactive dyes was chosen Ostazine Black V-B (see Figure 3). 
In their experiments was used a Kratos Kompact MALDI III mass spectrometer (Manchester, UK) controlled by Kratos Kompact V5.2.0 software, equipped with a nitrogen laser VSL-337D-10-TTL from Laser Science Inc. (Franklin, MA, USA) operating at $337 \mathrm{~nm}$ with pulse energy $250 \mathrm{~mJ}$, average power at $10 \mathrm{~Hz} 2.5 \mathrm{~mW}$ and peak power $85 \mathrm{~kW}$.

After the optimization of the working conditions it was found that the reflectron negative mode is optimal, because under any conditions there were no signals obtained in positive mode for the substances studied. A laser power of 100 relative power units was used (maximum 180) with 2- (4-hydroxyphenylazo) benzoic acid as the matrix. The matrix was diluted in acetonitrile $/ 0.5 \%$ ammonium citrate $1: 1$ $(\mathrm{v} / \mathrm{v})$. The ammonium citrate was found to not only suppress a number of sodium adducts, but also enhance the homogeneity of the crystals of dried sample.

As a result of these experiments the authors concluded that Using MALDITOFMS in reflectron negative mode, given sample of Ostazine Black V-B and its derivatives were determined with the LOD approximately $100 \mathrm{mg} / \mathrm{l}$, and the method is suitable for immediate estimation of the dye-bath content during the dyeing process. Moreover using MALDI-TOF-MS it was possible to run 60 samples per $h$, while using HPLC it is possible to carry out just four experiments per $h$.

In conclusion, MALDI-TOF-MS it is a useful tool in textile industry. Its applications can be found again for characterization of textile fibers, identification of toxic compounds in cloth, but also for identification and characterization of textile dyes.

\section{References}

1. J. Roboz, Introduction to Mass Spectrometry Instrumentation and Techniques, Wiley, New York, 1968.

2. K. Tanaka, H. Waki, Y. Ido, S. Akita, Y. Yoshida, and T. Yohida, Rapid Commun. Mass Spectrom., 1988, 2, 151.

3. M. Karas, D. Bachmann, U. Bahr, and F. Hillenkamp, Int. J. Mass Spectrom. Ion Proc., 1987, 78, 53.

4. M. Karas, D. Bachmann, and F. Hillenkamp, Anal. Chem., 1985, 57, 2935.

5. M. Karas and F. Hillenkamp, Anal. Chem., 1988, 60, 2299.

6. J. T. Stults, Curr. Opin. Struct. Biol., 1995, 5, 691-8.

7. D. J. Harvey, J. Chromatogr. A, 1996, 720, 429-46.

8. T. Bonk and A. Humeny, Neuroscientist, 2001, 7, 6-12.

9. E. J. Zaluzec, D. A. Gage, and J. T. Watson, Protein Expr. Purif, 1995, 6, 109-23.

10. R. Zenobi and R. Knochenmuss, Mass Spectrom. Rev., 1999, 17, 337.

11. D. Momcilovic, B. Wittgren, K.-G. Wahlund, J. Karlsson, and G. Brinkmalm, Rapid Commun. Mass Spectrom., 2003, 17, 1116.

12. D. Momcilovic, B. Wittgren, K.-G. Wahlund, J. Karlsson, and G. Brinkmalm, Rapid Commun. Mass Spectrom., 2003, 17, 1107.

13. M. Karas, M. Gluckmann, and J. Schafer, J. Mass Spectrom., 2000, 35, 1.

14. D. J. Harvey, Mass Spectrom. Rev., 1999, 18, 349.

15. R. Knochenmuss, A. Stortelder, K. Breuker, and R. Zenobi, J. Mass Spectrom., 2000, 35, 1237. 
16. S. J. Wetzel, C. M. Guttman, and J. E. Girard, Int. J. Mass Spectrom., 2004, 238, 215.

17. J. Schiller, R. Suss, J. Arnhold, B. Fuchs, J. Lessig, M. Muller, P. M., H. Spalteholz, O. Zschornig, and K. Arnold, Prog. Lipid Res., 2004, 43, 449.

18. Y. Q. Shen, H. D. Tang, and S. J. Ding, Prog. Polym. Sci., 2004, 29, 1053.

19. L. H. Cohen and A. I. Gusev, Anal Bioanal. Chem., 2002, 373, 571.

20. S. F. Macha and P. A. Limbach, Curr. Opin. Solid State Mat. Sci., 2002, 6, 213.

21. P. Jungblut and B. Thiede, Mass Spectrom. Rev., 1997, 16, 145.

22. 2O. P. Gur'janov, T. A. Gorshkova, M. Kabel, H. A. Schols, and J. E. G. van Dam, Carbohydr. Polym., 2007, 67, 86.

23. R. Girault, F. Bert, C. Rihouey, A. Jauneau, C. Morvan, and M. Jarvis, Int. J. Biol. Macromol., 1997, 21, 179-188.

24. C. Mooney, T. Stolle-Smits, H. Schols, and E. de Jong, J. Biotechnol., 2001, 89, 205-216.

25. R. D. Holland, F. Raffi, T. M. Heinze, J. B. Sutherland, K. J. Voorhees, and J. O. Lay Jr., Rapid Commun. Mass Spectrom., 2000, 14, 911.

26. G. Montaudo, F. Samperi, and M. S. Montaudo, Prog. Polym. Sci., 2006, 31, 277-357.

27. L. J. Soltzberg, A. Hagar, S. Kridaratikorn, A. Mattson, and R. Newman, J. Am. Soc. Mass Spectrom., 2007, 18, 2001-2006.

28. H. Chroma-Keull, J. Havlis, and J. Havel, Rapid Commun. Mass Spectrom., 2000, 14, 40-43. 